\begin{tabular}{c} 
International Journal of Engineering \& Technology, 7 (3) (2018) 1881-1887 \\
International Journal of Engineering \& Technology \\
SPC \\
Website: $\begin{array}{c}\text { ww. sciencepubco.com/index.php/IJET } \\
\text { doi: } 10.14419 / \text { ijet.v7i3.13977 } \\
\text { Research paper }\end{array}$ \\
\hline
\end{tabular}

\title{
Exploring the challenges confronting the west Africa climate system
}

\author{
Emetere M. E ${ }^{\cdot 1,2 *}$, Akinyemi M. L ${ }^{1}$, Ojewumi M. E ${ }^{3}$, Muhammad B. $\mathbf{M}^{4}$ \\ ${ }^{1}$ Department of Physics, Covenant University Canaan land, P.M.B 1023, Ota, Nigeria \\ ${ }^{2}$ Department of Mechanical Engineering Science, University of Johannesburg, Auckland Park Kingsway, Johannesburg South Africa \\ ${ }^{3}$ Department of Chemical Engineering, Covenant University Canaan land, P.M.B 1023, Ota, Nigeria \\ ${ }^{4}$ Department of Science, The Federal Polytechnic Bida, Nigeria \\ *Corresponding author E-mail: emetere@yahoo.com
}

\begin{abstract}
The peculiar location of West Africa on the World map suggests that the region is prone to be under severe atmospheric influences from other regions. With a population of over 300 million people, the human activity and its corresponding impact on the climate system of the region is worth noting. The meteorological exploration of funded projects like AERONET, AMMA, DACCIWA etc. in West Africa shows the peculiarity of the danger that life-forms in West Africa might be facing in the next two decades. The documentation of salient discoveries over the West Africa Monsoon and whose challenges may be the possible answers to questions on the West Africa climate system. A re-view on the satellite exploration within 2002-2006 shows the anomalies which require intense concern by all and sundry.
\end{abstract}

Keywords: West Africa; West Africa Monsoon; West Africa Climate System; Ground Observation; Satellite Observation

\section{Introduction}

The West Africa (WA) region occupies a strategic location of the African Continent. The region is located at the north of the equator and westward into the Atlantic Ocean. The region is unique because it encompasses major climatic zones. WA comprises of a dense rain forest along the coastal belt and extends to the sub-Sahelian savanna in the north. There are over 72 million hectares of forest in West Africa (Mari et al., 2011) which contributes to its ozone distribution. The life form activities within WA are somewhat unique via the aerosol loadings throughout each year. The aerosol loadings across this region is uncontrolled for now (Emetere et al., 2017a,b; Emetere 2016; Omotosho et al., 2015) due to industrial, agricultural, Sahara dust and domestic activities. This region experiences monsoon signatures such as distinct seasonal shift in the prevailing winds and alternation between winter dry conditions and summer rainy conditions (e.g. Janicot et al., 2011). The WA region is made up of about eighteen countries namely Nigeria, Ghana, Benin, Burkina Faso, Cameroun, Cape Verde, Cote d'Ivoire, Equatorial Guinea, Gambia, Guinea, Guinea Bissau, Liberia, Mali, Mauritania, Niger, Senegal, Sierra Leone and Togo (Figure 1). According to the United States agency, the population of human in WA is over 300 million (Feedthenation, 2015). The predominant occupation is agriculture; hence, agricultural pollution from biomass burning is expected to be relatively high. Thus, undoubtedly the aerosol loading over WA has influenced its climate system. The explorative activities of funded projects (such as the AErosol RObotic NETwork (AERONET), the African Monsoon Multidisciplinary Analyses (AMMA), the Dynamics-aerosol-chemistry-cloud interactions in West Africa (DACCIWA) efforts, the West Africa Climate DR\&D Project, the Saharan West African Monsoon Multiscale Analysis (SWAMMA), the West African Science Service Center on Climate Change and Adapted Land Use (WASCAL)) projects to unravel the climatic structure of WA and its relation to global climate has yielded much results with its peculiar challenges which are mainly financial.

DACCIWA is a project in WA funded by the European Union 7th Framework Program. The major objective is to investigate the effect of emissions on the atmospheric composition over South and West Africa. The type of emissions-targeted include anthropogenic and natural. AERONET is a project funded by managed by NASA's Goddard Space Flight Center and PHOtométrie pour le Traitement Opérationnel de Normalisation Satellitaire (PHOTONS). The project has over 18 ground-based sun photometers at different sites to measure aerosol optical thickness around WA. Most of the sites are not fully functional. The challenges would be discussed in one of the section. AMMA is an international project which started in 2003 (Redelsperger et al., 2006) and its major objective is to unravel the West African monsoon (WAM) and its variability. The AMMA project spreads across many locations of WA. AMMA utilizes satellite data and diverse modelling studies. WASCAL is a large-scale project that focuses on designed programs to assist to monitor and tackle climate change challenges in West Africa. SWAMMA is funded by NERC and its primary objective is to evaluate the role of Saharan monsoon, deep cumulonimbus convection and Saharan dust over Africa. The end-goal is to determine the extent to which seasonal rainfall affects the monsoon's boundary conditions- provided by the global climate system. West Africa Climate DR\&D Project is intended to predict the frequency of droughts and flooding in WA and to investigate the extent of involvement of the WA weather to understand the spread of common diseases like malaria, dengue and yellow fever.

In this paper, we shall be discussing the features of the West African climate i.e. its Monsoon, funded meteorological projects within WA and their challenges. The main finding of this paper is that there is an utmost need to revamp the ground stations in West Africa. 


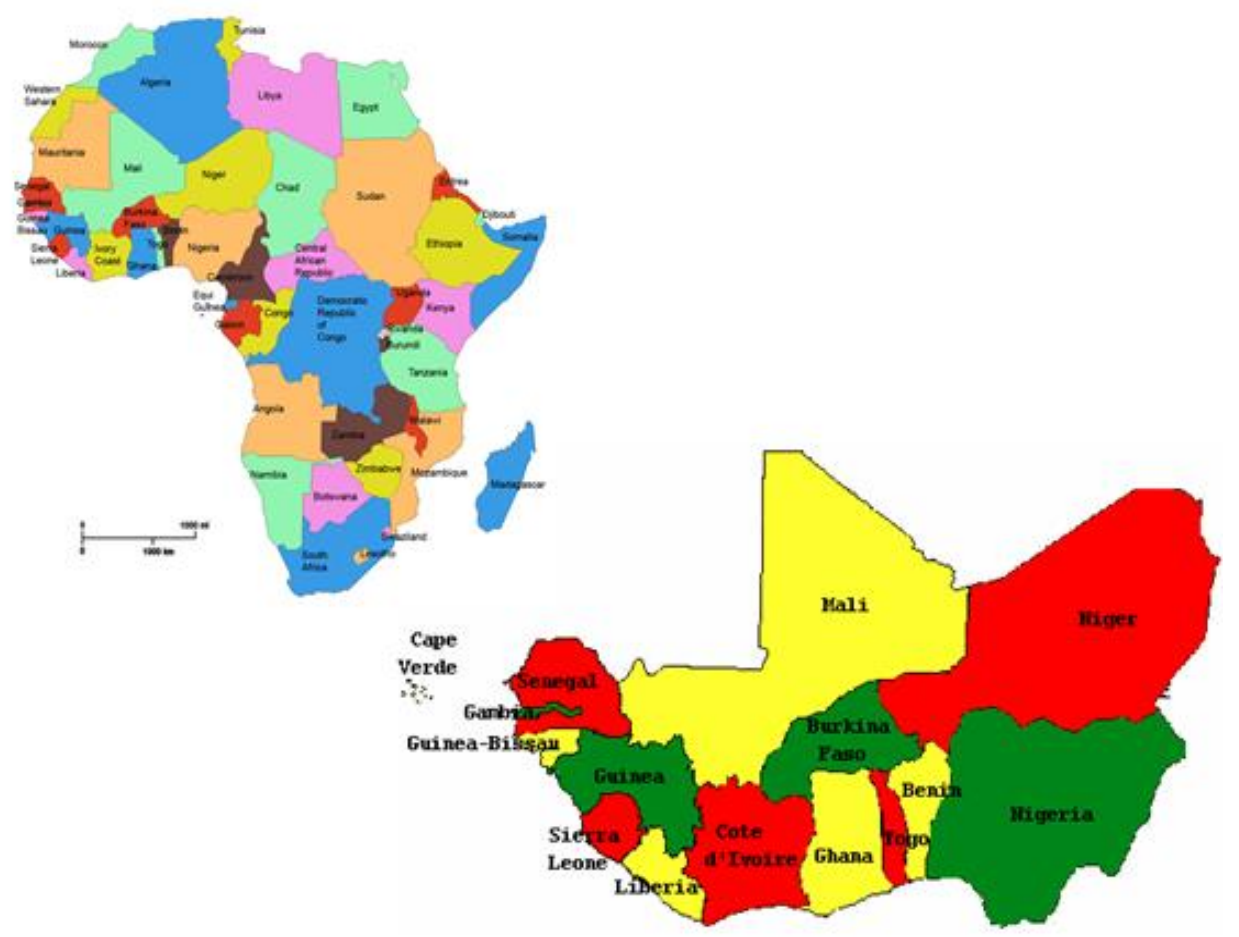

Fig. 1: Map of West Africa.

\section{The features of the west African climate sys- tem}

The West African Monsoon (WAM) is characterized by strong precipitation and rich vegetation at the coastal regions of Nigeria, Ghana, Togo, Cape Verde, Cote d'Ivoire, Liberia, Sierra Leone, Guinea, Gambia and Senegal. Its precipitation variability is affected by many factors e.g. global climate teleconnections and the yearly aerosol loading. The aerosol loading over WA can be monitored by aerosol optical depth measurements. Aerosol Optical Depth (AOD) is a vital parameter that applies to determining air quality that affects environment and life-forms; monitoring volcanic and biomass pollution; forecasting and now-casting earth radiation budget and climate change; estimating variability of aerosols and its size distribution in the atmosphere. AOD can be measured using either ground (sun photometer) or remotely sensed technique. AERONET is a typical known for harnessing ground measurements. It gives quality data on all aerosol column properties. However, it has a major limitation of few operational stations in developing and remote regions like WA. The principle of remotely sensed technique is based on the ability of satellite to capture particulates in the atmosphere via reflection and absorption of visible and infrared light. Remote sensed technique is available on some site. For example, Aura/OMI are used to obtain aerosol optical depth at ground pixel resolution i.e. $0.25 \mathrm{o}$ latitude/longitude grid and 1o latitude/longitude grid resolution; Meteor-3, TOMS and NIMBUS 7 are used to obtain aerosol optical depth at ground pixel resolution i.e. 1o X $1.25 \mathrm{o}$ latitude/longitude grid resolution. Other satellite sites for obtaining AOD are Moderate Resolution Imaging Spectroradiometer (MODIS), Advanced Very High Resolution Radiometer (AVHRR), MEdium Resolution Imaging Spectrometer (MERIS), Polarization and Directionality of the Earth's Reflectances (POLDER) over ocean and Multi-angle Imaging SpectroRadiometer (MISR), Advanced Along Track Scanning Radiometer (AATSR), Total Ozone Mapping Spectrometer (TOMS), Ozone Monitoring Instrument (OMI), MODIS, Atmospheric Infrared Sounder (AIRS), TIROS Operational Vertical Sounder (TOVS) over land.

Global climate teleconnections includes climatic oscillations and regional climate systems. The climatic oscillation includes El Nino-
Southern Oscillation and North Atlantic Oscillation. The North Atlantic Oscillation originates eastward from the southwestern North Atlantic to Portugal and WA. The North Atlantic Oscillation is responsible for the abnormalities in temperature and precipitation patterns (NOA, 2015). El Nino-Southern Oscillation (ENSO) is referred as the most influential natural fluctuation of climate that occurs on interannual time-scales. ENSO originates in the tropical Pacific and extends globally to all climate systems. The Maden-Julian Oscillation (MJO) also influences temperature and precipitation patterns in Indian and West Africa monsoon. The regional climate systems include inter-tropical discontinuity, subtropical anticyclones, atmospheric winds, Jet stream, monsoons, sea surface temperature (SST) anomalies etc. Rainfall anomalies over the sub-Saharan of West Africa are primarily triggered by sea surface temperature (SST) anomalies (Nicholson, 2000).

West Africa region (WAR) experiences dry northeasterly winds coming from the Sahara Desert during the winter. This experience leads drastically to a reduction in rainfall. During summer season, WAR experiences low-level southwesterly winds and high rainfall rates (Hall et al., 2006). Popular models Global Circulation Models (GCMs) have failed to simulate-accurately rainfall in the past and present over West Africa. This is because rainfall patterns in West Africa are complex in nature. The general projections had been that the Sahelian coastline may experience a decrease in precipitation by around 15 to $20 \%$ by 2100 (IPCC, 2007). These coupled general circulation models (CGCMs) has different parameterizations to represent sub-gridscale processes such as clouds and boundary layer turbulence. They typically have different horizontal and vertical resolutions, hence, they enhance coupling between the atmosphere, ocean and land surface. Traditional CGCMs are unable to capture the monsoon because they cannot represent the complex, multiscale interactions known to be associated with the monsoon. This explains the limitation of traditional models. Traditional model compulsorily parameterize sub-grid scale processes. This makes the traditional model to capture the important feedbacks that occur between small scale convection.

The topography of WAM is characterized by forest along the Guinea coast in the south of the region, shrub and grasslands in the Sahel in the mid-region, bare soil and desert in the north of the region. However, the largest aerosol emission sources in the WAM 
are the mineral dust from Sahara and Sahel through its northern region and biomass burning smokes from the southern region. The WAM is also influenced by propagating mesoscale convective systems to the planetary scale circulation that drives the monsoon winds (Hall et al.,, 2006). Haung et al., (2008) reported that the aerosol-related can be traced back to African dust and smoke sources. For example, there is a reduction of precipitation when aerosol is anomalously high. This is mostly experienced during boreal cold season i.e. from late autumn to winter. Generally, the onset of the monsoon is typically in June - during the wet season. In the lower troposphere (LT) of WAM, the wind flow is characterized by the south-westerly while the upper troposphere (UT) is characterized by the Tropical Easterly Jet (Peyrille et al., 2007). Within the troposphere, the wind activity dictates the tropospheric ozone (Aghedo et al., 2007) which is initiated by biogenic emissions of volatile organic compounds (VOCs) from West Africa. The West African region is reported to be one of the sources of biogenic nitrogen oxides from lightning (Schumann et al., 2007). Hao et al., (1994) affirmed that biomass burning in West Africa is linked to agricultural practice and other anthropogenic activities which are located at latitudes south of $10 \mathrm{o} \mathrm{N}$ and the Southern Hemisphere i.e. outside of West Africa (between the equator and 10o S). The aerosol composition of the troposphere in WAM was analyzed via the flying programme of the African Monsoon Multidisciplinary Analysis (AMMA) project (Lebel et al., 2009). Reeves et al., (2010) gave details of the flying programme of AMMA. The measurements were carried out via Special Observational Periods 1 and 2 (SOP 1 and SOP 2) with the aircraft loaded with different sensors for chemical measurements. SOP 1 targeted month of June (i.e. the onset of the Monsoon development) via five research aircraft (three based in Niamey, Niger and two in Ouagadougou, Burkina Faso). SOP 2 targeted the months of July and August 2006 (i.e. when monsoon onset is maximum) via another five research aircraft (three based in Niamey, Niger and two in Ouagadougou, Burkina Faso). The research aircraft had their specific function. For example, ATR-42 focused on the lower troposphere, BAe-146 on the lower and mid-troposphere, Falcons on the upper troposphere and M55 on the upper troposphere/lower stratosphere. The research aircraft made comprehensive measurements of aerosols and trace gases i.e. vertical and horizontal distribution from the planetary boundary layer to the lower stratosphere. The geographical location of the site ranges from $2 \mathrm{~N}$ to $21 \mathrm{~N}$, and between $10 \mathrm{~W}$ and $7 \mathrm{E}$.

The major climatic zone of West Africa as shown in figure (2) below- stretches across five latitudinal zones of $5^{\circ}$ each namely zones $0-5^{\circ} \mathrm{N}, 5-10^{\circ} \mathrm{N}, 10-15^{\circ} \mathrm{N}, 15-20^{\circ} \mathrm{N}$ and $20-25^{\circ} \mathrm{N}$. West Africa has a tropical climate though the far northern portion of West Africa is arid and stretches into the Sahara desert. The climatic zones of West Africa are shown in figure (2) below.

Raicich et al. (2003) discovered via observational analysis the relationships between the WA and the Mediterranean climate at interannual timescale. This discovery maybe hinged on Tropical Easterly Jet (TEJ) which circulates across West Africa during the boreal summer season. TEJ is associated with the Mediterranean climate and emanates from the Asian monsoon. The four different climatic zones in west Africa are Sahelian zone, Sudano-Sahelian zone, Sudanian zone and Guinean zone. Sahelian zone is a region of perennial vegetation, the average annual precipitation ranges between 250 and $500 \mathrm{~mm}$. The Sahel zone is dominated by the WAM. As discussed earlier, large-scale circulation-transporting moisture from the Atlantic Ocean into the land is expected in Sahel zone. The Sahel zone is also characterized by wind reversal in the lower atmosphere. Sudano-Sahelian zone is a region where average annual precipitation ranges from 500 to $900 \mathrm{~mm}$. Sudanian zone is a region of an average annual precipitation that ranges from 900 to $1100 \mathrm{~mm}$. Guinean zone is a region of an average annual precipitation exceeding $1100 \mathrm{~mm}$. Atmospheric circulation pattern in the four zones is controlled by some salient factors like African Easterly Jet (AEJ), Intertropical Convergence Zone (ITCZ), Intertropical Discontinuity (ITD), associated heat low (HL), Subtropical Jet (STJ), troughs and cyclonic centres associated with African Easterly Waves (AEW) and Tropical Easterly Jet (TEJ). AEJ operates at mid tropsphere (600-700mb) with maximum wind speed above $10 \mathrm{~m} / \mathrm{s}$ and travels to WA from the East Africa. The AEJ drives convection and rainfall patterns in the four climatic zones of WA (Andres et al., 2009). ITCZ also contributes to the convective rainfall pattern via the south-north-south displacement. The Sahelian, Sudano-Sahelian and Sudanian climate zone are characterize by desert dust. Hence, the aerosol loading in such location is high. Desert dust is deposited mainly by wind erosion. The finer dust particles diffuse to high altitudes and travels thousands of kilometers from its source (Mahowald et al., 2003). This action explains the continual influence of aerosol loadings over the West African climate system. According to Sauvage et al. (2005) and Haywood et al. (2008), the aerosol emission pattern in WA is closely related to the seasonal north-tosouth shift of the Inter-Tropical Convergence Zone (ITCZ). The AMMA project has studied the desert dust impact using groundbased lidars and airborne in-situ aerosol and gas measurements (Haywood et al., 2008). It was discovered that the desert dust transports via vertical distribution over WA during the dry monsoon. This pattern is influenced by the north-easterly Harmattan, AEJ and south-westerly trade winds.

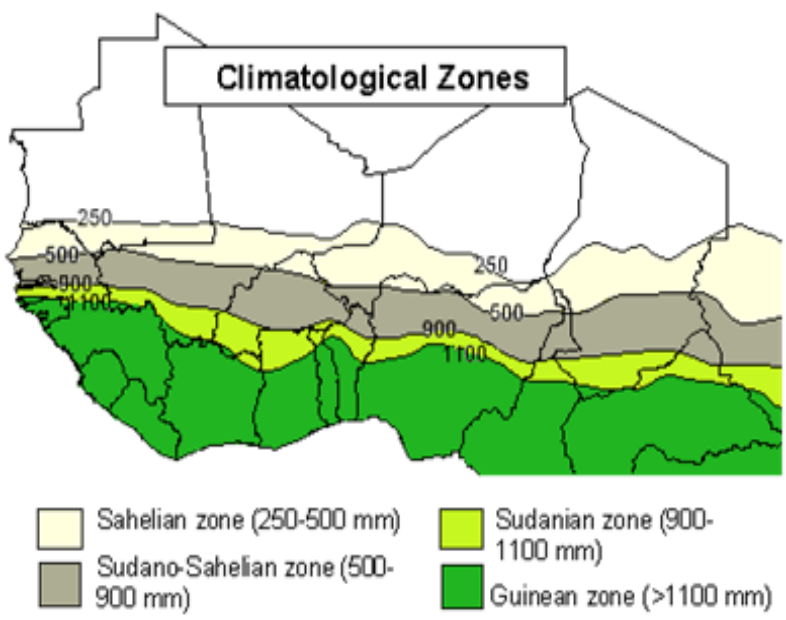

Based on mean annual rainfall 1961-90, SDRN-FAO Rome

Fig. 2: Climatic Zones in West Africa. Adopted From FAO.

\section{Meteorological exploration in west Africa and its challenges}

In the previous section, the satellite exploration techniques was listed and discussed. The satellite sensors also (like the sun photometer) have their operational biases. These biases are documented in literatures (Tompkins et al., 2005; Faccani et al., 2009). This is one of the reasons ground station measurements are preferred to the satellite measure. Another reason is that satellite measurement is limited beyond cloud-free pixels and has a reduced sensitivity in the lower atmosphere. The radiosonde (ground) stations are used to generate high digital vertical resolution of in situ wind, temperature, pressure, and humidity data. Financing radiosonde stations across the major parts of the West African monsoon is quite challenging. The introduction of funded projects (by AERONET, AMMA e.t.c.) to West Africa has enabled the present understanding of the WAM. For example, the jet streak of the AEJ has been discovered to extend $10 \mathrm{oE}$ via the AMMA experiment. Also, the funded projects have revealed that maximum aerosol optical depth occurs over West Africa (between 0 and $15 \mathrm{~N}$ ) in December, January and February. Therefore, we envisage more impactful meteorological influences in WA in the future. One of the present challenges of the funded projects in WA is the accuracy of the type of radiosonde. For example, the AMMA campaign in Africa used various radiosondes to execute their campaign. Each of the radiosondes are selected based on their biases in relative humidity measurements. The success of some of the sonde was limited due to specification of the manufacturer. In one of our recent study (yet unpublished), we propose that 
the aerosol layer in the atmosphere (see figure 3) results in multiple refractive indexes (MRI).

The MRI is said to influence atmospheric measurements and most unsuccessful campaign were not directly on the instrument but on the inability of the manufacturer to compute the right parameter (atmospheric constants) in the compact flash card. For example, Vaisala RS80-A sondes has large dry biases and Vaisala RS92 has weakly moist biases. Bock et al.(2008) documented the biases of the radiosonde except for MODEM M2K2 sondes whose humidity biases are not known. The unknown biases of the MODEM M2K2 sondes and the lost of TEMP messages from reliable (ground and satellite) stations is a further affirmation of the need to document the atmospheric constant over an area. Emphasis on the biases of the measuring instrument may be secondary at this moment. Nuret et al. (2008) admitted that the lost of TEMP messages from reliable stations is currently out of the scope of the AMMA project. This means that explorative scientists working on WA have a task of calculating the right atmospheric constants that manufacturers of radiosondes must work with. In our view, the atmospheric constant varies regionally because of the variance in aerosol loadings. Another challenge of the present ground station across WA is the maintenance of the station. Few AERONET station within WA has stopped operation while the existing station are not $100 \%$ functional based on the missing data available on http://aeronet.gsfc.nasa.gov/. Another challenge facing funded projects in WA is data gaps and assimilation problems (Faccani et al., 2009). For example, the convergence location of moisture in the Sahel climate zone is still unknown despite the availability of radiosonde stations across WA This challenge has necessitated the use of European Center for Medium range Weather Forecasting (ECMWF) bias correction for AMMA measurements (Faccani et al., 2009). This development shows that the number of radiosonde station over WA is inadequate to understand the in-depth features of WAM. Since the quality of forecast is based data accuracy as well as developing accurate models, the nowcast or forecast of metrological station in WA is still questionable.

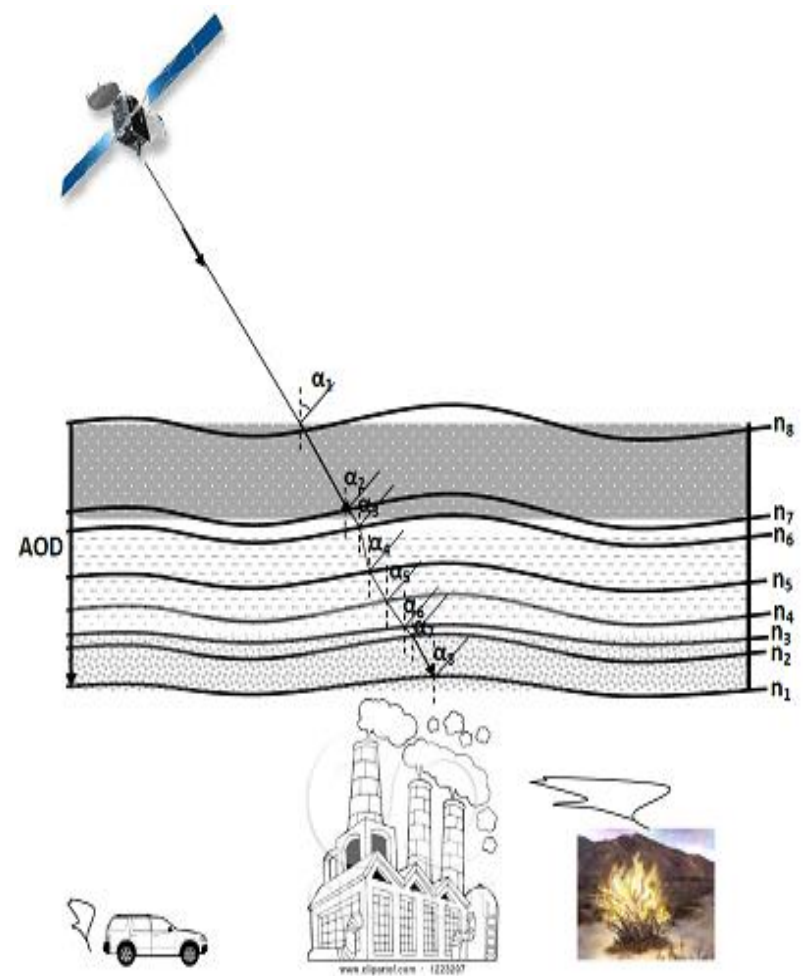

Fig. 3: Illustration of the Multiple Refractive Indexes.
One of the advantages of satellite observation over ground observation is the enabled overview of the meteorological performance over any location. For example, the ozone distribution over West Africa showed significant south-north gradient with lower and higher values over forested regions and the north of $12 \circ \mathrm{N}$ respectively (Adon et al., 2010); the emission of emit large amounts of biogenic volatile organic compounds (VOCs), NOx and $\mathrm{O} 3$ are observed over the boundary layer in the Sahelian climate zones (Ferreira et al., 2010; Stewart et al., 2008; Jaegle et al., 2004); the activities of the mesoscale convective systems (MCS) over the northern edge of the West African ITCZ in Sahel climate zone can be monitored (Mohr, 2004). Though there had been successful satellite exploration in WA, the need for ground-trotting is eminent. For example, the aerosol-water cycle interactions over WA are currently investigated in the DACCIWA project. Janicot et al. (2008) had explained the physics of the transporting marine and biogenic air masses and the dust-laden north-easterly dry winds. However, the success of the current DACCIWA project may shed more light into the complexity of the condensation nuclei $(\mathrm{CCN})$ in WA. At this stage, satellite observations of tropical gravity waves (GW) over West Africa have not been properly explained by models. Interestingly, the AMMA project have launched a ground observation and observed the relation between deep convection and GW (Kafando et al.2008). The objective of this section is to show the urgent need of a comprehensive ground-trotting project in WA. We highlighted the aerosol loading over WA using the Total Ozone Mapping Spectrometer (TOMS) Aerosol Index (AI) and its corresponding effect over salient metrological parameters between 2002-2006. The meteorological parameter imagery was gotten from the Modern Era Retrospective analysis for Research and Applications (MERRA). The remote effect of aerosol loading over WA was observed only over Nigeria (Figure $4 \& 5$ )

Figure 4a represents the aerosol loading for January on the TOM Ai for 2002, figure $4 \mathrm{~b}$ represents the aerosol loading for the month of April on the TOM Ai for 2002, figure 4c represents the aerosol loading for the month of July on the TOM Ai for 2002, figure $4 \mathrm{~d}$ represents the aerosol loading for October on the TOM Ai for 2002, figure $4 \mathrm{e}$ represents the cloud top temperature $(\mathrm{K})$ for 2002 via the MERRA observation, figure $4 \mathrm{f}$ represents the total surface precipitation $(\mathrm{Kg} / \mathrm{m} 2 / \mathrm{s})$ for 2002 via the MERRA observation, figure $4 \mathrm{~g}$ represents the atmospheric mass $(\mathrm{Kg} / \mathrm{m} 2)$ for 2002 via the MERRA observation and figure $4 \mathrm{~h}$ represents the absorbed longwave at the surface $(\mathrm{W} / \mathrm{m} 2)$ for 2002 via the MERRA observation. Also, figure $4 \mathrm{i}$ represents the aerosol loading for January on the TOM Ai for 2003, figure $4 \mathrm{j}$ represents the aerosol loading for the month of April on the TOM Ai for 2003, figure $4 \mathrm{k}$ represents the aerosol loading for the month of July on the TOM Ai for 2003, figure 41 represents the aerosol loading for October on the TOM Ai for 2003, figure $4 \mathrm{~m}$ represents the cloud top temperature (K) for 2003 via the MERRA observation, figure $4 \mathrm{n}$ represents the total surface precipitation $(\mathrm{Kg} / \mathrm{m} 2 / \mathrm{s})$ for 2003 via the MERRA observation, figure 4o represents the atmospheric mass $(\mathrm{Kg} / \mathrm{m} 2)$ for 2003 via the MERRA observation and figure $4 \mathrm{p}$ represents the absorbed longwave at the surface $(\mathrm{W} / \mathrm{m} 2)$ for 2003 via the MERRA observation. The same sequence of numbering is followed in figure 5 for 2004 and 2005. The aerosol loading for January (figure 4 and 5) drove the cloud top temperature. This is possible (from literature) because of the roles of the vertical diffusion pattern and lifetime of aerosol, water vapour, $\mathrm{CCN}$ e.t.c.. These main factors dictate the heat absorption both at the cloud-top and cloud-bottom. It is also observed that the aerosol loading in January do not significantly affect the total surface temperature, atmospheric mass and the absorbed longwave at the surface (Akinwumi et al., 2017; Odigwe et al., 2013; Usikalu et al., 2017; Emetere and 

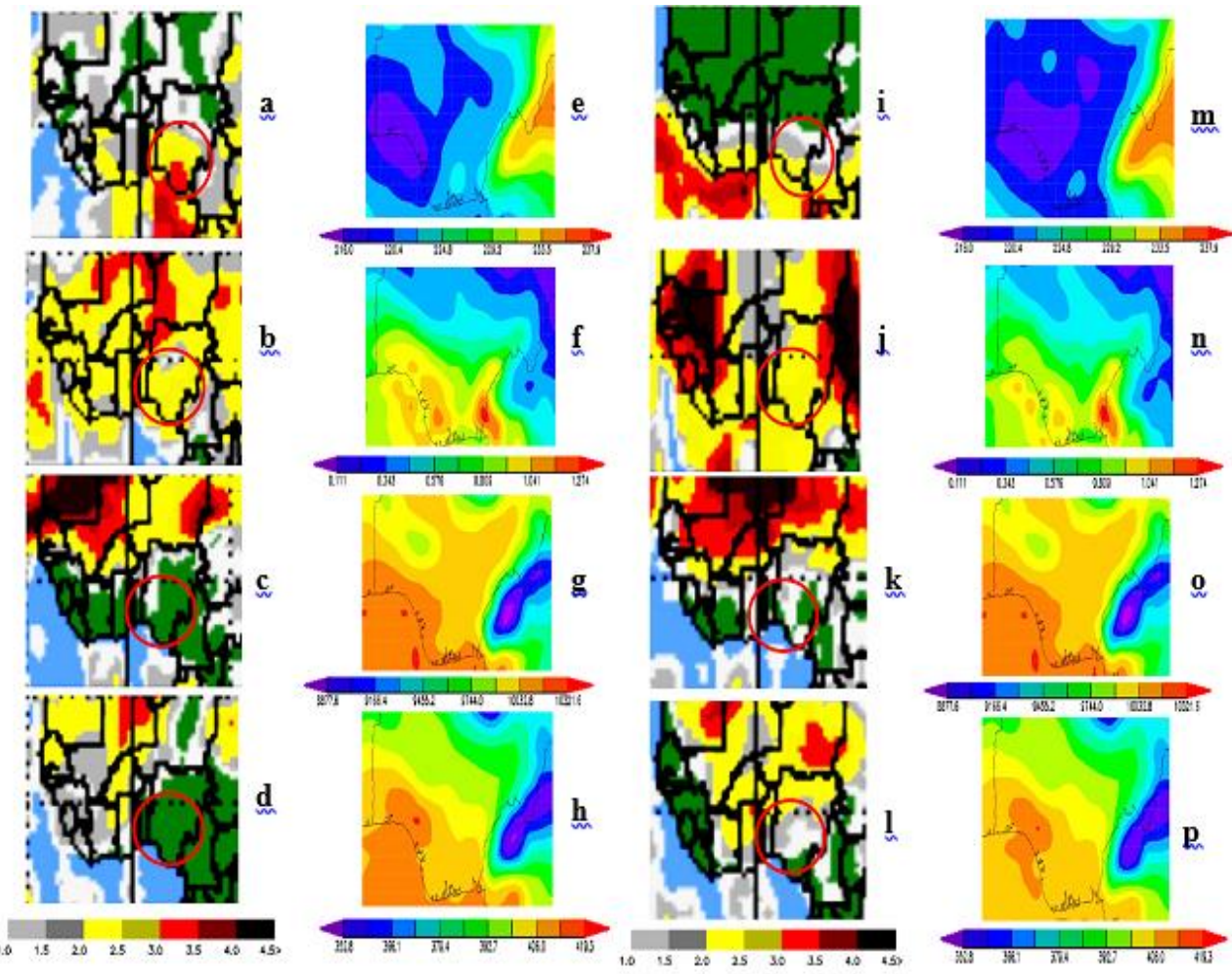

Fig. 4: Satellite Exploration of Aerosol Initiated Events for 2002 (Fig 4a-H) and 2003(Fig 4i-P).

Akinyemi, 2017). Whatever explanation adduced to this observation may be misleading because only two radiosondes are located in the area (Lagos and Ilorin). The vertical column activities of the aerosol size distribution alongside the common or uncommon individual-influences of the ITCZ, AEJ, GW, STJ, TEJ or ITD should be known. This observation extends to other countries in the West Africa region. Therefore, we recommend a more robust driven meteorological exploration which will be demanding-financially. Taking a cue from the over 11 million Euros DACCIWA budget (Knippertz, 2013) for three research aircrafts and a wide range of surfacebased instrumentation at three sites (Ghana, Benin and Nigeria), the cost to unravel discoveries about the WAM calls for the active participation of the government of the West Africa states and an uncompromised synergy of all funded projects within WA.

\section{Conclusion}

The West African region can be regarded as the deposition site for global atmospheric influences. Though there have been significant successes in the meteorological exploration of WA, much
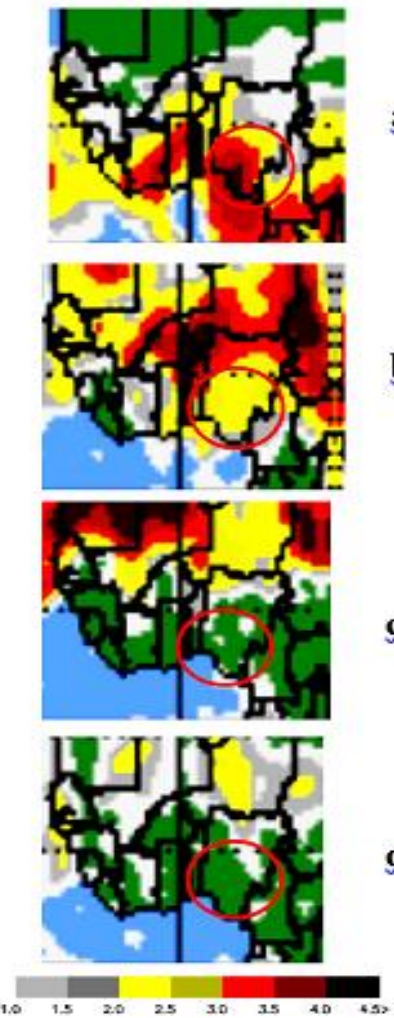

a

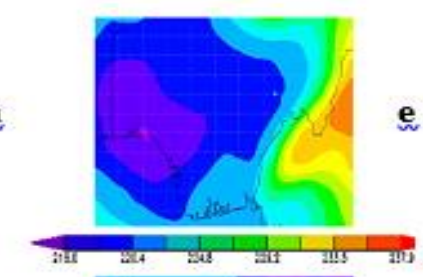

b

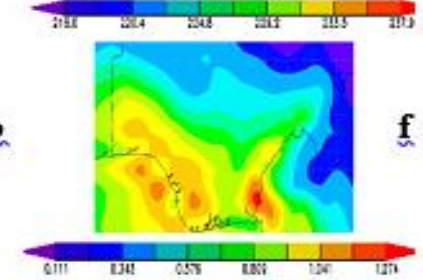

c

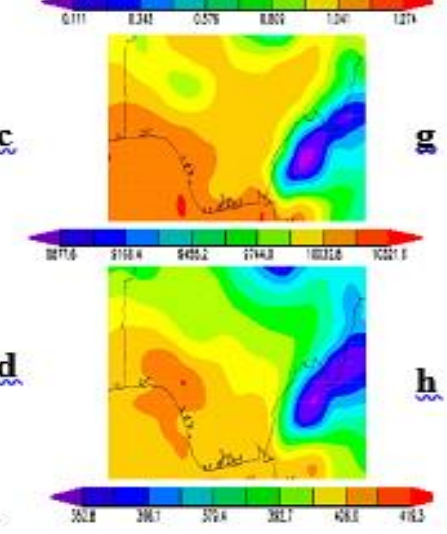

e

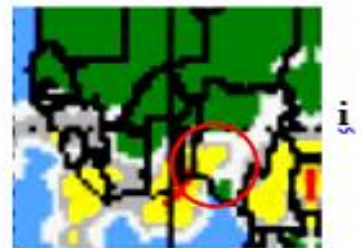

\section{i}

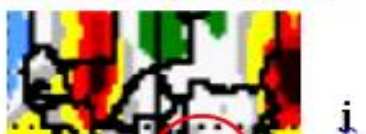

j
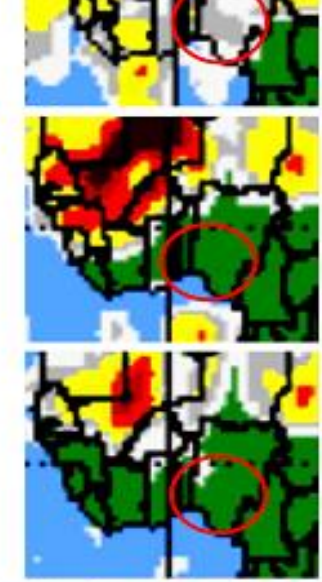

$\mathbf{k}$
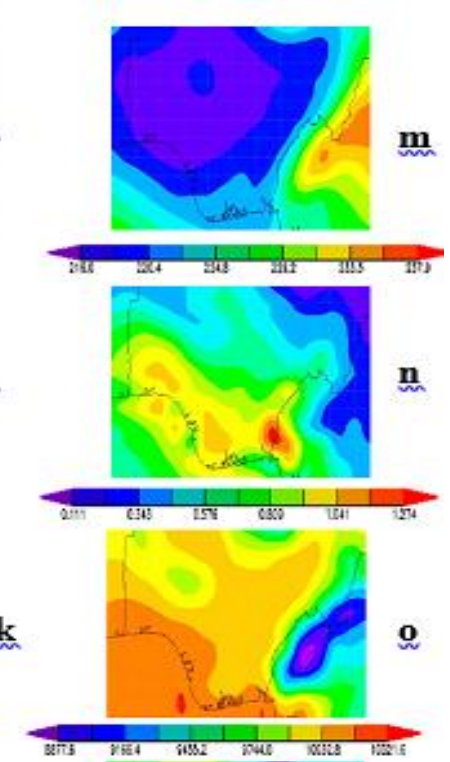

1

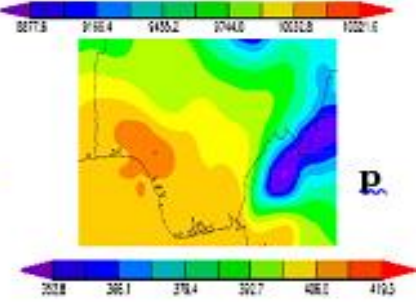

Fig. 5: Satellite Exploration of Aerosol Initiated Events for 2004 (Fig 5a-H) and 2005 (Fig 5i-P). 


\section{Acknowledgement}

The authors appreciate Covenant University for partial sponsorship. The authors acknowledge the use of NASA dataset for the research. Emetere M.E. enjoys partial funding as Senior Research Associate at University of Johannesburg.

\section{References}

[1] Adon M, Galy-Lacaux C, Yoboue V, Delon C, Lacaux JP, Castera P Gardrat E, Pienaar J, Al Ourabi H, Laouali D, Diop B, SighaNkamdjou L, Akpo A, Tathy JP, Lavenu F, Mougin E., Long term measurements of sulfur dioxide, nitrogen dioxide, ammonia, nitric acid and ozone in Africa using passive samplers. Atmospheric Chemistry and Physics Discussion 10: 4407-4461 (2010) https://doi.org/10.5194/acpd-10-4407-2010.

[2] Aghedo, A. M., Schultz, M. G., and Rast, S., The influence of African air pollution on regional and global tropospheric ozone, Atmos. Chem. Phys., 7, 1193-1212, (2007) https://doi.org/10.5194/acp-71193-2007.

[3] Akinwumi SA, Omotosho TV, Willoughby AA, Emetere ME., Sectional Investigation of Seasonal Variations of Surface Refractivity and Water Vapour Density over Nigeria, International Journal of Applied Engineering Research 12 (14), 4587-4598 (2017).

[4] Andres-Hernandez MD, Kartal D, Reichert L, Burrows JP, Meyer Arnek J, Lichtenstern M, Stock P, Schlager H., Peroxy radical observations over West Africa during AMMA 2006: photochemical

Activity in the outflow of convective systems. Atmospheric Chemistry and Physics 9: 3681-3695 (2009) https://doi.org/10.5194/acp-9 3681-2009.

[5] Bock O, Bouin MN, Doerflinger E, Collard P, Masson F, Meynadier R, Nahmani S, Koit'e M, Gaptia Lawan Balawan K, Did'e F, Ouedraogo D, Pokperlaar S, Ngamini JB, Lafore JP, Janicot S, Guichard F, Nuret M., and The West African Monsoon observed with ground-based GPS receivers during AMMA. Journal of Geophysical Research 113: D21105.

[6] Emetere, Moses E., Investigations on aerosols transport over microand macro-scale settings of West Africa, Environ. Eng. Res., 22(1), 75-86 (2017). https://doi.org/10.4491/eer.2016.080.

[7] Emetere, Moses E. Impacts of recirculation event on aerosol dispersion and rainfall patterns in parts of Nigeria, GLOBAL NEST JOURNAL 19 (2), 344-352 (2017). https://doi.org/10.30955/gnj.002142.

[8] ME Emetere and ML Akinyemi. Documentation of atmospheric constants over Niamey, Niger: a theoretical aid for measuring instruments, Meteorological Applications 24 (2), 260-267, (2017). https://doi.org/10.1002/met.1624

[9] Emetere M.E., Generation of Atmospheric Constants over Some Locations in West Africa: A Theoretical Aid for Measuring Instruments Design, International Journal of Engineering Research in Africa, 27: $119 \quad$ - 146, (2016). $\quad$ https://doi.org/10.4028/www.scientific.net/JERA.27.119.

[10] FAO, Global Information and Early Warning System on food and agriculture Report No 1 - 9 June 2004 http://www.fao.org/docrep/006/J2517e/J2517e00.htm (2004).

[11] Faccani C, Rabier F, Fourrie N, Agust'1-Panareda A, Karbou F, Moll P, Lafore JP, Nuret M, Hdidou FZ, Bock O., The impact of the AMMA radiosonde data on the French global assimilation and forecast system. Weather and Forecasting 24: 1268-1286 (2009) https://doi.org/10.1175/2009WAF2222237.1.

[12] Feedthenation, http://www.feedthefuture.gov/country/west-africaregional (Retrieved 20/06/2015)

[13] Ferreira J, ReevesCE, Murphy JG, Garcia-Carreras L, Parker DJ, Oram DE., Isoprene emissions modelling for West Africa using MEGAN. Atmospheric Chemistry and Physics Discussion 10: 69236953 (2010) https://doi.org/10.5194/acpd-10-6923-2010.

[14] Hall, N.M.J and P. Peyrille, Dynamics of the West African monsoon J. Physique, 139, 81-99 (2006) https://doi.org/10.1051/jp4:2006139007.

[15] Hao, W. M. and Liu, M. H.: Spatial and temporal distribution of tropical biomass burning, Global Biogeochem. CY. Eight, 495-503 (1994) https://doi.org/10.1029/94GB02086.

[16] Haywood, J. M., Pelon, J., Formenti, P., Bharmal, N. A., Brooks, M., Capes, G., Chazette, P., Chou, C., Christopher, S., Coe, H., Cuesta J., Derimian, Y., Desboeufs, K., Greed, G., Harrison, M., Heese, B.,
Highwood, E. J., Johnson, B. T., Mallet, M., Marticorena, B., Marsham, J., Milton, S., Myhre, G., Osborne, S. R., Parker, D. J., Rajot, J.-L., Schulz, M., Slingo, A., Tanre, D., and Tulet, P: Overview of the Dust and Biomass burning Experiment and African Monsoon, Multidisciplinary Analysis Special Observing Period-0, J. Geophys. Res., 113, D00C06, https://doi.org/10.1029/2007JD009451.

[17] Huang, J., C. Zhang, J. M. Prospero. 2008: Large scale effects of aerosol on rainfall over West Africa, Quarterly Journal of the Royal Meteorological Society, (www.interscience.wiley.com) DOI: 10.1002/qj.391.(2009).

[18] IPCC, Summary for Policymakers. In: Climate Change 2007: The Physical Science Basis.

[19] Contribution of Working Group I to the Fourth Assessment Report of the Intergovernmental Panel on Climate Change [Solomon, S., D. Qin, M. Manning, Z. Chen, M. Marquis, K. B. Averyt, M. Tignor and H. L. Miller (Eds.)]. Cambridge University Press, Cambridge, United Kingdom and New York, NY, USA. (2007).

[20] Janicot, S., G. Caniaux, F. Chauvin, G. de Coëtlogon, B. Fontaine, N. Hall, G. Kiladis,

[21] Intraseasonal variability of the West African monsoon, Atmospheric Science Letters, 12, 58-66. doi:10.1002/asl.280 (2011) https://doi.org/10.1002/asl.280.

[22] Janicot, S., Thorncroft, C. D., Ali, A., Asencio, N., Berry, G., Bock,O., Bourles, B., Caniaux, G., Chauvin, F., Deme, A., Kergoat, L., Lafore, J.-P., Lavaysse, C., Lebel, T., Marticorena, B., Mounier, F., Nedelec, P., Redelsperger, J.-L., Ravegnani, F., Reeves, C. E., Roca, R., de Rosnay, P., Schlager, H., Sultan, B., Tomasini,M., Ulanovsky, A., and ACMAD forecasters team: Large-scale overview of the summer monsoon over West Africa during the AMMA field experiment in 2006, Ann. Geophys., 26, 2569-2595(2008) https://doi.org/10.5194/angeo-26-2569-2008.

[23] Jaegle, L., Martin, R. V., Chance, K., Steinberger, L., Kurosu, T. P., Jacob, D. J., Modi, A. I., Yoboue, V., Sigha-Nkamdjou, L., and GalyLacaux, C.: Satellite mapping of rain-induced nitric oxide emissions from soils, J. Geophys. Res.-Atmos., 109, D21320, https://doi.org/10.1029/2004JD004787.

[24] Kafando, P., Chane-Ming, F. and M. Petitdidier, Climatology of gravity wave activity during theWest African Monsoon, Ann. Geophys., 26, 4081-4089 (2008) https://doi.org/10.5194/angeo-264081-2008.

[25] Lebel, T., Parker, D. J., Flamant, C., Bourles, B., Marticorena, B., Mougin, E., Peugeot, C., Diedhiou, A., Haywood, 5 J. M., Ngamini, J. B., Polcher, J., Redelsperger, J.-L., and Thorncroft, C. D.: The amma field campaigns: Multiscale and multidisciplinary observations in the west african region, Q. J. R. Meteorol. Soc, https://doi.org/10.1002/qj.486.

[26] Mari C'eline H. , Claire E. Reeves, Katherine S. Law, G'erard Ancellet, Maria Dolores Andr'es-Hern'andez, Brice Barret, Joelle Bechara, Agn`es Borbon, Idir Bouarar, Francesco Cairo, Roisin Commane, Claire Delon, Matthew J. Evans, Federico Fierli, C'edric Floquet, Corinne Galy-Lacaux,1 Dwayne E. Heard, Carine D. Homan, Trevor Ingham, Niels Larsen, Alastair C. Lewis, Catherine Liousse, Jennifer G. Murphy, Emiliano Orlandi, David E. Oram, Marielle Saunois, Dominique Serca, David J. Stewart, Daniel Stone, Valerie Thouret, Peter van Velthoven and Jason E. Williams, Atmospheric composition of West Africa: highlights from the AMMA international program,Atmos. Sci. Let. 12: 13-18 (2011).

[27] Mohr, K. I., Interannual, Monthly, and Regional Variability in the Wet Season Diurnal Cycle of Precipitation in Sub-Saharan Africa, J. Climate, 17, 2441-2453 (2004). Of Precipitation in Sub-Saharan Africa, J. Climate, 17, 2441-2453 (2004).https://doi.org/10.1175/15200442(2004)017<2441:IMARVI>2.0.CO;2.

[28] Mahowald NM, Kiehl LM., Mineral aerosol and cloud interactions. $\begin{array}{llll}\text { Geophys. } & \text { Res. } & \text { Lett. } & 30 \text { : }\end{array}$ https://doi.org/10.1029/2002GL016762.

[29] Nuret M, Lafore JP, Bock O, Guichard F, Agust'1-Panareda A, Ngamini JB, Redelsperger JL., Correction of humidity bias for Va1sala RS80 sondes during AMMA 2006 Observing Period. Journal of Atmospheric and Oceanic Technology 25: 2152-2158 (2008). https://doi.org/10.1175/2008JTECHA1103.1.

[30] NOA, http://www.cpc.ncep.noaa.gov/products/assessments/assess_96/nao.html, (Retrieved 20/06/2015)

[31] Nicholson, S.E, the Nature of Rainfall Variability over Africa on Time Scales of Decades to Millenia. Global and Planetary Change 26, 137-158 (2000) https://doi.org/10.1016/S0921-8181(00)000400 .

[32] Odigwe Ishioma Ani, Oluwakorede Olakunle Ologun, Oluwaseyi Olatokun, Awelewa Ajibola 
[33] Ayokunle, Ayoade Felix Agbetuyi, Samuel Adekunle Isaac, A Microcontroller-Based.

[34] Active Solar Water Heating System for Domestic Applications, 4(3):262 (2013).

[35] Omotosho, T.V., Emetere, M.E., Arase, O.S., Mathematical projections of air pollutants effects over Niger Delta region using remotely sensed satellite data International Journal of Applied Environmental Sciences, 10(2), 651-664 (2015).

[36] Peter Knippertz,Dynamics-aerosol-chemistry-cloud interactions in West Africa, www.dacciwa.eu.

[37] Peyrille, P., Lafore, J. P., and Redelsperger, J. L.: An idealized twodimensional framework to study the West African monsoon. Part i: Validation and key controlling factors, J. Atmos. Sci., 64, 2765-2782 (2007) https://doi.org/10.1175/JAS3919.1.

[38] Reeves C. E., P. Formenti, C. Afif, G. Ancellet, J.L. Attie, J. Bechara A. Borbon, F. Cairo, H. Coe, S. Crumeyrolle, F. Fierli, C. Flamant, L. Gomes, T. Hamburger, C. Lambert, K. S. Law, C. Mari, A. Matsuki, J. Methven, G. P. Mills, A. Minikin, J. G. Murphy, J. K. Nielsen, D. E. Oram, D. J. Parker, A. Richter, H. Schlager, A. Schwarzenboeck, and V. Thouret, Chemical and aerosol characterisation of the troposphere over West Africa during the monsoon period as part of AMMA, Atmos. Chem. Phys. Discuss., 10, 71157183 (2010) https://doi.org/10.5194/acpd-10-7115-2010.

[39] Redelsperger, J. L., C. D. Thorncroft, A. Diedhiou, T. Lebel, D. J. Parker, and J. Polcher, African Monsoon Multidisciplinary Analysis: An international research project and field campaign, bull. Am. Meteorol. Soc., 87, 1739-1746 (2006) https://doi.org/10.1175/BAMS87-12-1739.

[40] Raicich F., Pinardi N and A. Navarra, "Teleconnections between Indian monsoon and Sahel rainfall and the Mediterranean," International Journal of Climatology, vol. 23, no. 2, pp. 173-186 (2003) https://doi.org/10.1002/joc.862.

[41] Stewart DJ, Taylor CM, Reeves CE, and McQuaid JB., Biogenic nitrogen oxide emissions from soils: Affect NOx and ozone over West Africa during AMMA (African Monsoon Multidisciplinary Analysis): observational study. Atmospheric Chemistry and Physics 8: 2285-2297 (2008) https://doi.org/10.5194/acp-8-2285-2008.

[42] Schumann, U. and Huntrieser, H.: The global lightning-induced nitrogen oxides source, Atmos. Chem. Phys., 7, 3823-3907 (2007). https://doi.org/10.5194/acp-7-3823-2007. 